\title{
The Visual Character Implementation of Wayang Figures in Branding Design in Vocational High School Through Students' Critical Thinking Ability and Creativity
}

\author{
Gunawan $^{1, *}$ Trie Hartiti Retnowati ${ }^{2, * *}$
}

\author{
${ }^{1}$ Arts Education Graduate Program, Yogyakarta State University, Depok 55281, Yogyakarta, Indonesia \\ ${ }^{2}$ Department of Fine Arts Education, Yogyakarta State University, Depok 55281, Yogyakarta, Indonesia \\ *Corresponding author.Email: goen82@gmail.com \\ ** Corresponding author.Email: trihartiti54@gmail.com
}

\begin{abstract}
Branding is one of the competencies that must be mastered by vocational students, especially students majoring in Visual Communication Design. In the current era of globalization, Brands are needed to give an identity as well as to introduce something, both the products and companies. Brands from various parts of the world enter many countries freely, and vice versa, the consumers or target markets can freely search for the product or company they want. In the process of designing Branding within the scope of vocational education, students must be competent in creating a Brand through a selection of names, logo designs, and application media. The concept of logo design must also have characteristics that distinguish it from that of the competitor companies. The application of visual character of wayang figures that is synchronized with the character of the product or company through the $21^{\text {st }}$-century skills is also intended to welcome the industrial era 4.0 in which the creative process and critical thinking of students are expected to bring up a Brand concept that is both unique and original. The visual character of the wayang figures is seen as having local wisdom and has many philosophies of meaning so that when applied in the design of Branding, it will produce a Brand with characters.
\end{abstract}

Keywords: visual characters, wayang figures, Branding, critical thinking, creativity

\section{INTRODUCTION}

In the field of Vocational High School (VHS) education, Visual Communication Design (VCD) program has the role of developing a creative economy. This is shown by the government effort to put the program in a sub-sector, namely Indonesian Creative Economy Agency/Bekraf. This agency has the authority of building the visual communication design subsector in both national and international levels. Thus, an excellent opportunity is provided for graphic designers and VCD graduates looking for and then obtaining jobs in this ASEAN Economic Community era. Work publication and promotion serve as a steppingstone for VCD graduates to obtain jobs in both local and international companies so that they are not less competitive with designers abroad.

In this study, the researchers focus on the basic competency of a learning material namely Branding. With logo design as the sub-competency, wayang characters serve as the concepts of the brand being made. The use wayang (a classical Javanese puppet) characters as a logo starts with the selection of product and company characters. This is done to match the meaning of the brand with both product and company characters. Creativity and critical thinking are the most prominent subjects in creating a company brand based on wayang characters.

In this industrial era $4.0,21^{\text {st }}$-century skills such as creativity and critical thinking skills need to be mastered by VCD majored students to be able to compete in the world of work. Character selection and logo design are the simulation for students to create a good and meaningful logo through wayang character analysis, semiotic, branding theories, creativity, and critical thinking. 


\section{THEORETICAL REVIEW}

\subsection{Wayang Character}

Wayang has various characters that differ visually and philosophically. According to Mahendra Sucipto, wayang is a representation of a soul, its characters resemble human characters, and it has their universe [1]. Learning wayang means learning yourselves and basic human qualities. Through stories about the characters, people can learn a set of meanings that inspire a human's life journey.

A process in which a student takes to select a wayang character for a brand is almost the same as modelling theories proposed by Bandura. Bandura states that modelling is a process of imitating by adding or eliminating the behaviours being observed. In branding, this strategy is done to synchronize the company and product characters [2].

Wayang characters used in branding are mostly popular among the public, especially students. Mahabharata and Ramayana are two major epics originated from India. Indonesians are good at imitating and at the same time making those two stories more interesting than that of the original. Wayang characters from those popular epics have become the feature of brands.

\subsection{Semiotics}

Barthes in Vera states that semiology is about how humans make meaning of things [3]. In this discipline, making meanings is different from communicating. It means that objects not only convey information and communicate but also constitute a structured system of signs.

Visual Communication Semiotics is an effort to add an interpretation of semiotics itself. Semiotics is a method of reading visual communication works. In the semiotic system, visual communication serves the function of 'communication', so that it builds a connection between the sender and receiver of the message, by employing certain media [4].

\subsection{Branding}

Brand is one of the most important attributes of a product in which the use is currently very widespread for several reasons because brands add more value to the product. According to Kotler and Gary Armstrong, a brand is a name, term, sign, symbol, design, or combination of those aspects. Brands are intended to make people recognize the products or services [5]. A brand may be a logo supported by meaningful typography or colours.

\subsection{1. $\operatorname{Logo}$}

Logo is a visual form of a product or company identity. Logos are applied in various media promotion as a form of visual communication that functions as the company identity [6].

\subsection{Typography}

Typography is a branch of science that focuses on letters with two functions, namely aesthetic and communication. Serving the aesthetic function, typography is used to support the look of a product so that messages can be delivered well. Meanwhile, communication is used to deliver messages in the form of texts clearly and correctly [7].

\subsubsection{Color}

Color is an exact element to touch the visual sensitiveness so that it can stimulate a person's feelings and interests. Color is subjective because when it is strongly connected to each individual who sees it, it will cause color symptoms on the objects seen so that it can change human perception. In relation to the logo, color is a very important element in its role as a reminder media [7].

\subsection{Creativity}

Torrance in Munandar chooses the process definition of creativity, explaining the relationship between the four P's by focusing on the creative process; what kind of individual can succeed in the process, what kind of environments can support the process, and what kind of product produced by the creative processes. Creativity is a person's ability which involves four dimensions, namely person, press, process, and product [8].

The theory is relevant to the student learning process in schools, with the student as the actor, the teacher as the support, the learning process as the process, and the work as the product.

\subsection{Critical Thinking}

Critical thinking is defined as an effort to see the truth of information by employing evidence, logic, and awareness of bias [9] [10]. The increasingly complex social conditions and advances in information technology encourage a rapid exchange of unverified information that serves as the reason for critical thinking.

Critical thinking skills are needed in branding design. This is the main source for communicating the logo design made so that the design can be accounted for. 


\section{RESEARCH METHOD}

This is a qualitative study done by observing social phenomena and problems using certain methodologies. Using this approach, researchers designed a complex picture, examines words, and conducted studies in natural situations.

\section{RESULTS AND DISCUSSION}

In basic competences in creating brand concepts and designing logos in the graphic computer course, students are given tasks of creating a product or company brand using visual characters of wayang characters. It begins by identifying the company character made into a brand and then determining the character of wayang made into the company brand.

In the next stage, the students brainstorm to create the design concepts with creative ideas based on the results of the previous stage before creating a logo design presented in the figure below:
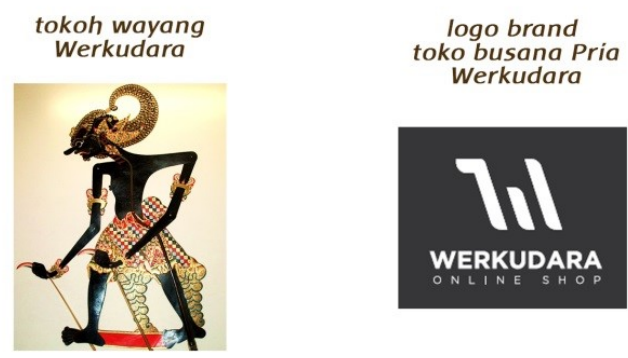

Tokoh Wayang Werkudara = Werkudara wayang character

Logo brand toko busana pria Werkudara = Men's clothing store logo brand

Figure 1 The example of Werkudara character which is made into a Brand (private document)

The logo design is created through semiotic analysis, branding theoretical analysis, and wayang character identification before using computer technology. Werkudara is known as a superior man. Thus, it becomes the main consideration of selecting the figure. The students also think critically in identifying the icons and signs. They put the Werkudara main feature and Pancanaka nails as the logo icon by using the letter $\mathrm{W}$ or the initial of Werkudara.

The element of creativity adds the meaning of the designed logo. The typography used displays the modern characters representing the online shop company. The color used in this logo gives a simple but elegant impression.
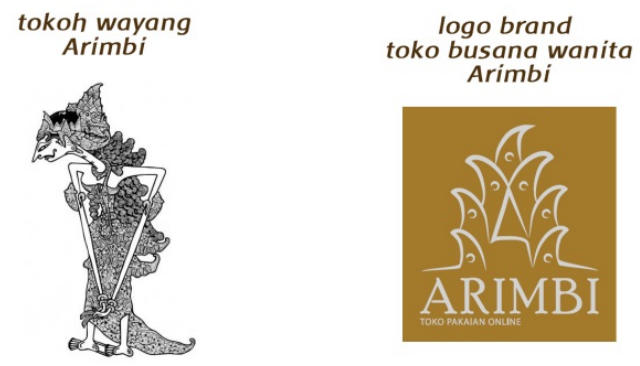

Tokoh Wayang Arimbi = Arimbi wayang character

Logo brand toko busana wanita Arimbi $=$ Women's clothing store logo brand

Figure 2 Arimbi character made into a brand

The next logo design is from the women's clothing store brand, taking the female wayang character named Arimbi. Arimbi has two characters to present a single philosophy. The first character is a giant possessing supernatural power. Then, the second character relies on her ability to turn into a very beautiful woman. From both characters, students can create a brand concept showing the wishes of becoming a greater store in the years ahead. Meanwhile, the second characters represent the product being sold. The symbol put in the logo design is the crown with a symbol as the initial name of Arimbi. The type of letter used in the brand is aimed at supporting the concept made before.

Creativity and critical thinking skills are competencies that students must master to design a brand, before later proceeding with logo design. Using semiotic analysis, logo design presents a strong concept in bringing out the expected meaning of an object, in this case, the visual character of the wayang character into a product or company. 


\section{CONCLUSION}

Brand design in vocational high education requires students to be competent in creating a brand by selecting a name and logo design and applying media. The logo design should have a particular character that defines it from other product or company logos.

Instilling wayang character into a brand is carried out by synchronizing the product character or company through the $21^{\text {st }}$-century skills. Moreover, to make students more prepared for the 4.0 industrial era, they are expected to design an interesting yet original brand concept. A wayang character is considered to bring local wisdom and philosophies so that when used in a brand, it has a strong character. It is expected that VCD students who are competent in branding go through the above stages to use the object of local wisdom beside wayang, but the implementation should be matched with the company character.

\section{REFERENCES}

[1] Mahendra, Sucipto. Kitab Lengkap Tokoh-tokoh Wayang [Complete Book of Wayang Figures]. Narasi Yogyakarta, 2016.

[2] Bandura, Albert, and Richard H. Walters. Social Learning Theory. Vol. 1. Englewood Cliffs, NJ: Prentice-hall, 1977.

[3] Vera, Nawiroh. Semiotika dalam Riset Komunikasi [Semiotics in Communication Research]. Bogor: Ghalia Indonesia, 2014. p. 26.

[4] Tinarbuko, Sumbo. Semiotika Komunikasi Visual: Metode Analisis Tanda dan Makna pada Karya Desain Komunikasi Visual [Semiotics of Visual Communication: The Method of Analysing Signs and Meanings in Visual Communication Design Work]. Jalasutra, 2008. p. xi.

[5] Kotler, Philip, and Gary Armstrong. Principles of Marketing. Pearson Education, 2010. p. 70.

[6] Carter, David E. The New Big Book of Logos. New York: HBI, 2000

[7] Kusrianto, Adi. Pengantar Desain Komunikasi Visual [Introduction to Visual Communication Design]. Yogyakarta: Andi Offset, 2007. p. 76.

[8] Munandar, Utami. Pengembangan Kreativitas Anak Berbakat [Development of Gifted Children Creativity]. Jakarta: Rineka Cipta, 2009. p. 20.
[9] Halpern, Diane F. "Teaching critical thinking for transfer across domains: Disposition, skills, structure training, and metacognitive monitoring." American psychologist 53.4 (1998): 449. DOI: https://psycnet.apa.org/doi/10.1037/0003066X.53.4.449

[10] Larsson, Kristoffer. "Understanding and teaching critical thinking - A new approach." International Journal of Educational Research 84 (2017): 32-42. DOI: https://doi.org/10.1016/j.ijer.2017.05.004 